\section{Oral health of adult prisoners and factors that impact on oral health}

\author{
E. Heidari, ${ }^{* 1}$ C. Dickinson ${ }^{2}$ and T. Newton ${ }^{3}$
}

VERIFIABLE CPD PAPER

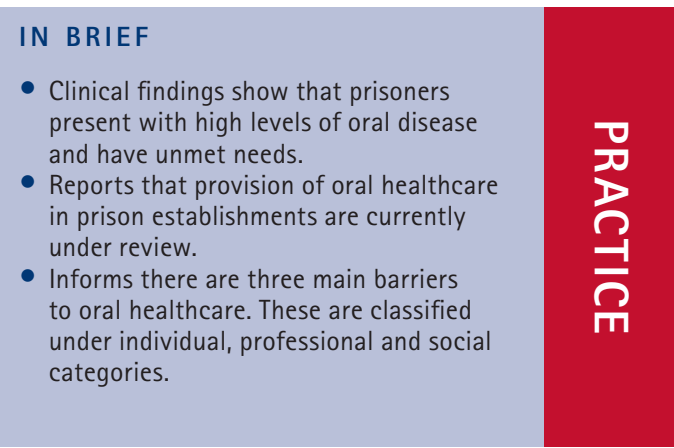

The first article in this series identified the medical and mental health issues among male patients in comparison to the
general population. This article will discuss the oral health of male prisoners and those factors that impact upon their oral
health including barriers to care. In general, the oral health of prisoners is poorer than that of age matched controls. A
variety of factors including health related behaviours and pre-confinement access to dental services can influence this.

\section{ORAL HEALTH OF PRISONERS: AN OVERVIEW}

There are few published studies available on prisoners' oral health in the United Kingdom, although some national centres have undertaken unpublished work. These studies have shown increased consumption of sugary drinks and food, drug abuse and oral neglect in the prison population. Studies have shown that people from lower socioeconomic classes do utilise preventive services less frequently and exhibit more unhealthy behaviours, ${ }^{1,2}$ such as smoking, drinking, consumption of unhealthy food ${ }^{2}$ and substance abuse. ${ }^{3}$ This correlates well with the clinical oral health findings, which demonstrate high levels of disease and unmet need. ${ }^{4}$

Most of the published literature on the oral health of prisoners has arisen from the United States of America, whose penal and healthcare systems are different and so difficult to compare with the UK situation. However, the prison population, from both the UK and USA, are commonly from similar socioeconomic backgrounds. They are mainly socially deprived single, young males (but the number of the older and the very young [18] prison population is on the increase). Prisoners in both countries also face similar challenges such as stress of imprisonment, mental and medical health

Senior Specialist Clinical Teacher, ${ }^{2}$ Consultant in Special Care Dentistry, ${ }^{3}$ Professor of Psychology as Applied to Dentistry, King's College London Dental Institute, Floor 26, Tower Wing. Guy's Hospital, Great Maze Pond, London, SE1 9RT

${ }^{*}$ Correspondence to: Dr Ellie Heidari

Email: ellie.heidari@kcl.ac.uk

\section{Refereed Paper}

Accepted 25 April 2014

DOI: 10.1038/sj.bdj.2014.594

${ }^{\circ}$ British Dental Journal 2014; 217: 69-71 issues, drug and substance misuse ${ }^{1,3,4}$ and access to care difficulties. ${ }^{5}$

Prisoners are likely to exhibit a higher degree of oral disease, a lower level of treatment and less motivation to maintain their oral health in comparison to the general population. Studies have demonstrated a trend towards an increased number of missing teeth and a higher DMFT index. ${ }^{4-11}$ There might be several reasons for this. Prisoners may seek dental treatment generally only when they are in pain. Their oral health values might be different in comparison to the general population. Alcohol and drug misuse $^{3}$ can mask dental pain. ${ }^{8}$ Before imprisonment they might not have had access to dental care and dental anxiety can reduce attendance. ${ }^{8}$ That is why it is not surprising to find that prisoners showed a mean of 3.5 to 4.2 decayed teeth whereas the general population in the UK have a mean of between 2.7 decayed teeth for all ages (16 to 85 and over). ${ }^{12}$ In one study, prisoners stated that they value their teeth and wish to maintain good oral health, but when asked about their wishes to save or extract a broken down tooth, many opted for extraction. ${ }^{8}$ Remand prisoners, because of their uncertain future and long waiting lists for dental treatment in prison might opt for extraction simply to relieve pain rather than choose treatments that may take longer. ${ }^{8}$

Not only do prison populations demonstrate a significantly higher number of decayed and missing teeth and fewer restored teeth compared with the non-prison population, they also exhibit higher periodontal disease and plaque level., ${ }^{7,8}$ Table 1 summarises data on caries experience in adult male prisoners from a range of studies in the UK and USA. ${ }^{4,6,8-11}$
In the USA, imprisonment status and length of sentence have an effect on prisoners' oral health. ${ }^{4,8,13}$ According to Mixson et al., ${ }^{9}$ prisoners who were in prison for less than two years utilised the dental services less and had more decayed teeth compared to long stay prisoners. This is also observed in the UK where generally the long stay, convicted prisoners have better oral health than the shorter stay remand prisoners, ${ }^{8}$ as they have the opportunity to take advantage of healthy lifestyles (for example, detox programmes, smoking cessation, healthy food options) and routine dental care treatment services. ${ }^{4,8}$ These findings support the speculation of several researchers that the reasons for improvement are likely to be that convicted prisoners use prison dental services more frequently than remand ones. ${ }^{1,4,6}$

\section{BARRIERS TO ORAL CARE}

There are three main types of barriers to the receipt of dental care: individual, professional and social. ${ }^{2,5,14}$ Individual barriers to dental care include lack of perceived needs, low long-term value of dental treatment, fear and anxiety. ${ }^{2,8,14,15}$ Professional barriers can be expressed as high cost, lack of resources and manpower, limited understanding of patient's needs, lack of training and inappropriate geographical distribution of dental services (the 'inverse care law'). ${ }^{16}$ This will lead to poor provision of services. Some healthcare professionals may have negative view of prisoners ${ }^{15}$ and consider their needs as a low priority. Unfortunately, such problems have been reported by vulnerable groups such as drug users when accessing dental services. ${ }^{15}$ Social factors can include lack of facilities, funding and workforce planning for prison dental services. 
The main barriers to dental service in prisons relates to access, affordability and availability. Waiting times are commonly long and services has traditionally been limited. ${ }^{1,4}$ In the UK, a dental contract (which details the amount of dental care provision sessions, the type of dental treatment that can be provided, how long a contract is valid for and its value) is arranged between commissioners and the oral healthcare providers in a prison setting. A dental contract might create barriers for prisoners' oral health in its establishment, especially if a dental contract only allows emergency dental care treatment for its prison population or has unrealistic units for treatment (UDA). There are numerous changes that have occurred in the UK since Public Health England (PHE), National Offender Management Service (NOMS), and NHS England became commissioners responsible for the provision of healthcare. ${ }^{17}$

Oral healthcare providers, together with other healthcare personnel in prison settings, can promote integration of oral health into general healthcare, prevention of disease and uptake of treatment. Healthcare workers have been previously, and can still be, faced with unrealistic performance and quality indicators that they need to achieve. However, the indicators will be looked at in the near future in order to reflect high demand. Currently, one of the indicators for prison dentistry is provision of emergency care by a dentist within 24 hours. ${ }^{18}$ Many of the prison establishments do not have contracts with oral healthcare providers to run sufficient dental care sessions for its prisoners during 'normal working hours' Out of hours care provision can prove to be impossible in many cases. Limited treatment sessions impact upon treatment targets and requirements. Additionally, provision of oral hygiene aids and products provided by prisons has been shown to be poor. ${ }^{19,20}$

\section{PRISON DENTAL SERVICES IN UK}

Oral healthcare in prison is free of charge. Dental services are generally demand-based with prisoners requesting to see the dentist or by referral from a prison medical officer. There are services that struggle to meet prisoners' expressed demands and can have long waiting lists for treatment. , $, 4,8,10,21^{\text {The gov- }}$ ernment document Strategy for modernising dental services for prisoners in England described the high oral health needs of prisoners $^{22}$ and played an important role in highlighting the prisoners' oral health needs, the role of the prison dentist and a need for improved dental facilities. However, as newer evidence has emerged this document needs to be updated. This is particularly important in the section on service provision where

\begin{tabular}{|c|c|c|c|c|c|c|c|}
\hline \multirow{2}{*}{ Study } & \multirow{2}{*}{$\begin{array}{l}\text { Sample } \\
\text { size }\end{array}$} & \multirow{2}{*}{$\begin{array}{l}\text { Mean } \\
\text { age }\end{array}$} & \multirow{2}{*}{ Age group } & \multicolumn{4}{|c|}{$\begin{array}{l}\text { Mean DMFT scores for male } \\
\text { prison population }\end{array}$} \\
\hline & & & & $\begin{array}{l}\text { Decayed } \\
\text { teeth }\end{array}$ & $\begin{array}{l}\text { Missing } \\
\text { teeth }\end{array}$ & $\begin{array}{l}\text { Filled } \\
\text { teeth }\end{array}$ & DMFT \\
\hline $\begin{array}{l}\text { Cunningham } \\
\text { et al. } 1985 \\
\text { (USA) }^{11}\end{array}$ & 99 & 22 & & 3.07 & 1.76 & 5.69 & 10.53 \\
\hline $\begin{array}{l}\text { Salive et al. } \\
1989 \\
\left(\text { USA }{ }^{6}\right.\end{array}$ & 178 & 30.8 & $\begin{array}{l}18-29 \\
30-44 \\
45+\end{array}$ & $\begin{array}{l}2.2 \\
3.4 \\
2.5\end{array}$ & $\begin{array}{l}3.4 \\
8.6 \\
16.7\end{array}$ & $\begin{array}{l}4.9 \\
5.1 \\
3.2\end{array}$ & $\begin{array}{l}10.5 \\
17.1 \\
22.4\end{array}$ \\
\hline $\begin{array}{l}\text { Mixson et al. } \\
1990 \\
(\text { USA })^{9}\end{array}$ & 191 & 37.5 & $\begin{array}{l}20-34 \\
35-44 \\
44+\end{array}$ & $\begin{array}{l}3.1 \\
2.3 \\
1.5\end{array}$ & $\begin{array}{l}3.0 \\
8.0 \\
14.0\end{array}$ & $\begin{array}{l}6.8 \\
6.2 \\
6.6\end{array}$ & $\begin{array}{l}12.9 \\
16.4 \\
22.1\end{array}$ \\
\hline $\begin{array}{l}\text { Lunn et al. } \\
2003 \\
(\text { UK) }\end{array}$ & 127 & & & 3.8 & 6.32 & 4.23 & 14.35 \\
\hline $\begin{array}{l}\text { Jones et al. } \\
2005 \\
(U K)^{4}\end{array}$ & 96 & & & 4.2 & & 4.7 & 15.4 \\
\hline $\begin{array}{l}\text { Heidari et al. } \\
2007 \\
(\text { UK) }\end{array}$ & $\begin{array}{l}78 \text { remand } \\
\text { prisoners }\end{array}$ & 35.7 & $\begin{array}{l}19 \text { to } 34 \text { for } 70 \% \\
\text { of the population }\end{array}$ & 3.5 & 6.2 & 4.5 & 14.2 \\
\hline
\end{tabular}

there was perhaps an underestimation of the number of dental care sessions required per establishment. Unfortunately, this document is still used by some commissioners when planning prison dental services.

There are currently discussions taking place between representatives from the National Association of Prison in UK (NAPDUK), ${ }^{23}$ NOMS and the Department of Health looking at commissioning, dental contract values, perceived and expressed needs, dental service provision per prisoner and quality of oral health kits. The aim is to explore areas that need improvement, to recommend pathways and encourage standardisation of the current prison dental systems and contracts. Currently, prison dental contracts can be provided by salaried services, general dental practitioners on a sessional or UDA basis and some have personal dental service (PDS) contracts.

\section{FACTORS THAT AFFECT ORAL HEALTH}

Three common behaviours among prisoners that have implications for oral health are smoking, excessive alcohol consumption and illegal drug use.

\section{Smoking}

There is a high prevalence of smoking in male prison populations (84\% in remand, $78 \%$ in sentenced prisoners). ${ }^{11}$ Tobacco use, besides causing staining and discolouration of the teeth, is an important risk factor for periodontal disease and alveolar bone loss. In smokers periodontal disease shows a dose/ exposure relationship ${ }^{24-27}$ with smokers who have smoked between 10 to 27 years having greater disease progression compared to non-smokers. ${ }^{26}$ Smoking is a major contributing factor to oral cancer and oropharyngeal cancer. ${ }^{28,29}$

Risk is increased if long term smoking is combined with a high frequency of consumption of alcohol. ${ }^{30}$

\section{Alcohol use}

Excessive use of alcohol is associated with the following oral health problems: caries, traumatised teeth, periodontal disease, ${ }^{30}$ tooth wear and xerostomia.

Tooth wear and erosion in alcohol users have been attributed to the low $\mathrm{pH}$ of alcoholic drinks and their gastric irritancy, which gives an increased risk of reflux and erosion.

\section{Illegal drug use}

Sheridan et al. ${ }^{15}$ and McGrath and Chan ${ }^{31}$ state that some of the following factors impact on oral health of drug users and contribute to their high risk of caries and periodontal disease:

- Poor eating habits and inadequate nutrition

- Craving for high sugar foods

- Poor oral hygiene ${ }^{8}$

- Smoking

- Fracturing or losing teeth due to accidental or non-accidental injury

- High levels of anxiety and needle phobia $^{8}$

- Irregular dental attendance

- Altered pain threshold

- Self-medication and masking of pain by opiates or other drugs 
- Avoidance of dentist until unbearable pain occurs.

Some drugs such as cocaine (which is a stimulant with a vasoconstrictive effect) can cause ulceration and atrophy of the tissues once rubbed on the gingivae and palate. This can lead to chemical irritation, abrasion, inflammation and ischaemic necrosis of the palate. ${ }^{31}$ The oral health problems can be exacerbated by detoxification regimes using sugared methadone syrup. This is because patients may hold the highly sugared and acidic substance in the mouth for a long period of time to maximise the effect. Some prisoners might even induce vomiting to benefit its effect. In turn, this exacerbates the risk of caries, erosion and xerostomia. ${ }^{31}$

\section{CONCLUSION}

The oral health of prison populations is disadvantaged in relation to non-prison populations. They show higher rates of general and oral disease. The high levels of normative oral health need can produce pressures on prison healthcare services and the unpredictable nature of remand prison life can make the delivery of services difficult. Prisoners can present with advanced disease because they come from lower socioeconomic classes, have unhealthy lifestyles and lack engagement with prevention and treatment services ${ }^{8}$ pre- and post-imprisonment.

Removing barriers and providing an available, acceptable and effective dental service for this vulnerable group is important. However, in order to provide high quality outcomes there is a need for innovative ways for improving prisoners' oral care and overcome the general and prison specific barriers to care. Future articles in this series will explore how such services could be implemented.
1. Treadwell H M, Northridge M E. Oral health is the measure of a just society. J Health Care Poor Underserved 2007; 18: 12-20.

2. Locker D. An introduction to behavioural science and dentistry. London: Tavistock/Routledge, 1989.

3. Department of health and NHS commissioning board. Public health functions to be exercised by the NHS commissioning board. Service specification No 29. Public health services for people in prison or other places of detention, including those held in the Young People's Secure Estate. London: DH, 2012.

4. Jones C M, Woods K, Neville J, Whittle J G. Dental health of prisoners in the North West of England in 2000: literature review and Dental Health Survey results. Community Dent Health 2005; 22: 113-117.

5. The Health and Social Care Information Centre. Access and barriers to care- a report from the Adult Dental Health Survey 2009. London: HSCIC, 2011. Online information available at http://www.dhsspsni. gov.uk/theme8_barriersandaccesstocare.pdf (accessed May 2014)

6. Salive M E, Carolla J M, Brewer T. Dental health of male inmates in a state prison system. J Public Health Dent 1989; 49: 83-87.

7. Naidoo S, Yengopal V, Cohen B. A baseline survey: oral health status of prisoners in Western Cape. SADJ 2005; 60: 24-27.

8. Heidari E, Dickinson C, Wilson R, Fiske J. Oral health of remand prisoner in HMP Brixton; London. Br Dent J 2007; 202: E1.

9. Mixson J M, Eplee H C, Fell P H et al. Oral health status of a federal prison population. J Public Health Dent 1990; 50: 257-262.

10. Lunn H, Morris J, Jacob A, Grummitt C. The oral health of a group of prison inmates. Dent Update 2003; 30: 135-138.

11. Cunningham A M, Glenn R E, Field H M et al. Dental disease prevalence in a prison population. $J$ Public Health Dent $1985: 45: 49-52$.

12. The Health and Social Care Information Centre Adult Dental Health Survey 2009 - summary report and thematic series. London: HSCIC, 2011. Online information available at www.ic.nhs.uk/pubs/dentalsurveyfullreport09 (accessed May 2014).

13. McGrath C. Oral health behind bars: a study of oral disease and its impact on the life quality of an older prison population. Gerodontology 2002; 19: 109-114.

14. Nuttall N M, Steele J G, Pine C M, White D, Pitts N B. The impact of oral health on people in the UK in 1998. Br Dent J 2001; 190: 121-126.

15. Sheridan J, Aggleton M, Carson T. Dental health and access to dental treatment: a comparison of drug users and non-drug users attending community pharmacies. Br Dent J 2001; 191: 453-457.

16. Cohen L K. Converting unmet need for care to effective demand. Int Dent J 1987; 37: 114-116.

17. NHS England, National Offender Management Service, Public Health England. National partnership agreement between: National Offender Management Service, NHS England and Public Health England for the co-commissioning and delivery of healthcare services in prisons in England. 2013. Online agreement available at http://www.justice.gov.uk/downloads/ about/noms/work-with-partners/national-partnership-agreement-commissioning-delivery-healthcareprisons2013.pdf (accessed May 2014).

18. HM Prison Service and Department of Health National Offender Management Service (NOMS). Guidance notes: prison health performance and quality indicators. London: Department of Health, 2008. Online guidance available at http://www.hpa.org.uk/webc/HPAwebFile/ HPAweb_C/1232006593707 (accessed May 2014).

19. Wright $D$, Allen C, Gibson B. A study of the perceived oral health and treatment needs of prisoners. Unpublished data: a review of the dental services in Kent prisons. HMP, 2001.

20. Heidari E, Dickinson C, Fiske J. Prisoner and lay opinions of a prison-issue oral health kit. J Disability Oral Health 2008; 9: 35-41.

21. Heidari $E_{1}$ Dickinson C, Fiske J. An investigation into the oral health status of male prisoners in the UK. $J$ Disability Oral Health 2008; 9: 3-12.

22. Department of Health. Reforming prison dental services in England: a guide to good practice. London: Department of Health, 2005.

23. National Association of Prison Dentistry (UK) Information available at www.napduk.org/ (accessed May 2014).

NB to Esther: Please could you add an author note highlighting that reference 23 is incomplete. Please can they clarify where the statistics cited in the main text can be found.

24. Baljoon $M$, Natto $S$, Bergstrom J. The association of smoking with vertical periodontal bone loss. $J$ Periodontol 2004; 75: 844-885.

25. Dietrich T, Bernimoulin J P, Glynn R J. The effect of cigarette smoking on gingival bleeding. J Periodontal 2004; 75: 16-22.

26. Razali M, Palmer M, Coward P, Wilson R F. A retrospective study of periodontal disease severity in smokers and non-smokers. Br Dent J 2005; 198: 495-498.

27. Johnson G K, Hill J M. Cigarette smoking and the periodontal patient. J Periodonto/ 2004; 75: 196-209.

28. Peterson P E. Oral cancer prevention and control-the approach of the World Health Organization. Oral Oncol 2009; 45: 454-60.

29. Peterson P E, Ogawa H. Strengthening the prevention of periodontal disease: the WHO approach. $J$ Periodontol 2005; 76: 2187-2193.

30. Araujo M W, Dermen K, Connors G, Ciancio S. Oral and dental health among inpatients in treatment for alcohol use disorders: a pilot study. J Int Acad Periodonto/ 2004: 6: 125-130.

31. McGrath $C$, Chan B. Oral health sensations associated with illicit drug abuse. Br Dent J 2005; 198: 159-162. 